\title{
SUKUK NEGARA DAN PEMBANGUNAN INFRASTRUKTUR DI INDONESIA
}

\author{
Anisa IImia \\ UIN Sunan Gunung Djati Bandung \\ anisailmia@uinsgd.ac.id
}

\begin{abstract}
The economic growth of a country is strongly influenced by the availability of infrastructure that will support various economic activities. The need for the availability of funds and infrastructure development is a dilemma given the limited sources of state budget revenue. The issuance of Sovereign Sukuk (SBSN) is one of the government's breakthrough to overcome this problem and is expected to be a solution option that can be used for infrastructure financing. This study aims to identify the development and contribution of Sovereign Sukuk (SBSN) for infrastructure development in Indonesia, include during the Covid-19 pandemic. From the results of data analysis using the library research method, its known that Sovereign Sukuk have a role as a source of APBN financing. The issuance of Sovereign Sukuk with various series of sukuk has contributed greatly to the develpoment of the various infrastructure projects in Indonesia. The total value of issuance and outstanding of Sovereign Sukuk also tends to increase every year which shows that Sovereign Sukuk is a financial instrument that is in demand by investors, both institutional investors and retail/individual investors because apart from being able to nvest, investors can also contribute to the country's development.
\end{abstract}

\section{Keywords : Infrastructure, Development, Financing, SBSN, Sovereign Sukuk}

\begin{abstract}
Abstrak
Pertumbuhan ekonomi suatu negara sangat dipengaruhi oleh ketersediaan infrastruktur yang akan menunjang berbagai kegiatan ekonomi. Kebutuhan akan ketersediaan dana dan pengembangan infrastruktur menjadi suatu hal yang dilematis mengingat terbatasnya sumber penerimaan anggaran negara. Penerbitan Sukuk Negara (SBSN) merupakan salah satu terobosan pemerintah untuk mengatasi masalah tersebut dan diharapkan menjadi opsi solusi yang mampu digunakan untuk pembiayaan infrastruktur. Penelitian ini bertujuan untuk mengidentifikasi perkembangan sukuk negara serta bagaimana kontribusinya bagi pembangunan infrastruktur di Indonesia termasuk pada saat terjadi pendemi Covid-19. Dari hasil analisis data dengan metode library research diketahui Sukuk Negara telah berperan sebagai sumber pembiayaan APBN. Penerbitan Sukuk Negara dengan berbagai macam seri sukuk telah memberi kontribusi yang besar dalam pembangunan berbagai proyek infrastruktur di Indonesia. Total nilai penerbitan dan outstanding sukuk negara pun cenderung mengalami peningkatan setiap tahunnya yang menunjukkan bahwa Sukuk Negara adalah instrument keuangan yang diminati oleh para investor, baik investor institusi maupun investor ritel/perorangan karena selain bisa berinvestasi, investor pun bisa berkontribusi dalam pembangunan negara.
\end{abstract}

Kata kunci : Infrastruktur, Pembangunan, Pembiayaan, SBSN, Sukuk Negara 


\section{Pendahuluan}

Infrastruktur memiliki pengaruh yang besar terhadap pertumbuhan ekonomi di mana ketersediaan infrastruktur yang memadai dalam suatu wilayah akan meningkatkan pertumbuhan ekonomi wilayah tersebut. Simon Kuznets menyatakan, pertumbuhan ekonomi suatu negara dipengaruhi oleh akumulasi modal (investasi pada tanah, peralatan, prasarana dan sarana dan sumber daya manusia),sumber daya alam, sumber daya manusia, baik jumlah maupun tingkat kualitas penduduknya, kemajuan teknologi, akses terhadap informasi, keuinginan untuk melakukan inovasi dan mengembangkan diri serta budaya kerja (Haryanto).

Pemerintah saat ini berusaha melakukan penambahan belanja negara yang sifatnya produktif, seperti pembangunan infrastruktur, pembangunan sarana dan prasarana publik, pembangunan konektivitas antar wilayah, pembangunan bandungan dan jaringan irigasi, perumahan untuk MBR KPR Sejahtera dan rumah susun. Data menunjukkan bahwa porsi pembiayaan infrastruktur terhadap total belanja negara dalam APBN terus meningkat dari tahun ke tahun.

Tabel 1. Anggaran Infrastruktur Negara

\begin{tabular}{|c|c|c|}
\hline Tahun & $\begin{array}{c}\text { Anggaran } \\
\text { Infrastruktur } \\
\text { (Triliun Rupiah) }\end{array}$ & $\begin{array}{c}\text { Pertumbuhan } \\
\text { (\%) }\end{array}$ \\
\hline 2014 & 157,4 & \\
\hline 2015 & 256,1 & 65,6 \\
\hline 2016 & 269,1 & 5,1 \\
\hline 2017 & 379,4 & 41,0 \\
\hline 2018 & 410,4 & 8,2 \\
\hline 2019 & 420,5 & 2,4 \\
\hline
\end{tabular}

Sumber : Website Kementerian Keuangan, 2020 (Data diolah)

Rencana pembangunan infrastruktur di Indonesia yang semakin beragam membawa dampak pada semakin besarnya beban pengeluaran negara karena tidak diimbangi dengan ketersediaan dana di mana saat ini penerimaan rutin negara dari sektor pajak belum bisa ditingkatkan sebanding dengan kebutuhan belanja negara. Upaya yang dilakukan agar negara memperoleh dana adalah dengan pinjaman luar negeri yang tentu saja akan membawa konsekuensi pada semakin besarnya beban utang negara dan menambah berat posisi neraca anggaran negara. Di sisi lain, utang luar negeri (termasuk bunga) yang semakin besar menambah beban neraca anggaran belanja negara (Khatimah, 2017).

Dalam usaha memenuhi gap financing demi menjaga tingkat pertumbuhan ekonomi dan pembangungan serta mengurangi keterikatan pemerintah pada utang luar negeri, dibutuhkan sumber pembiayaan lain yang aman dan bebas dari resiko utang luar negeri, diantaranya adalah penjualan Surat Berharga Negara (SBN) dan Surat Berharga Syariah Negara (SBSN) atau sukuk negara (Hakim,2011).

Di pasar keuangan Indonesia, penerbitan sukuk baik di pasar dalam negeri maupun pasar internasional untuk pembiayaan deficit APBN dan pembiayaan pembangunan infrastruktur dimulai sejak adanya undang-undang Nomor.19 tahun 2008 tentang Surat Berharga Syariah Negara (SBSN). Salah satu pertimbangan munculnya Undang-undang ini adalah bahwa potensi sumber pembiayaan pembangunan nasional yang menggunakan instrument keuangan berbasis syariah yang memiliki pelung besar belum dimanfaatkan secara optimal (UU No.19/2008). Dengan adanya undang-undang ini maka sukuk sebagai instrument keuangan syariah memiliki 
kepastian hukum pasti dan berpeluang untuk senantiasa berkontribusi terhadap aktivitas perekonomian dan pembangunan negara. Pada hakikatnya, sukuk adalah surat berharga berupa sertifikat atau bukti kepemilikan aset dikeluarkan oleh emiten kepada pemegang obligasi syariah (sukuk) berdasarkan prinsip syariah. Sukuk bukan instrument utang piutang dengan bunga (riba) seperti obligasi dalam keuangan konvensional, tetapi sebagai instrumen investasi. Penerbitan sukuk dilakukan dengan suatu underlying asset dengan prinsip syariah (Huda \& Nasution,2007).

Sukuk Negara menjadi salah satu instrument investasi bagi para investor sekaligus instrumen pembiayaan Anggaran Pendapatan dan Belanja Negara (APBN) selain juga berkontribusi terhadap perkembangan industry keuangan di Indonesia maupun internasional (Laporan Perkembangan Keuangan Syariah Indonesia LPKSI, 2018). Sebagai instrument investasi, Sukuk Negara merupakan media bagi public untuk berkontribusi langsung terhadap pembangunan melalui pembelian sukuk di mana public juga dapat menerima keuntungan langsung berupa imbal bagi hasil atau yield. Sukuk Negara menjadi sumber pembiayaan APBN yang akan digunakan untuk mempercepat berbagai pembangunan infrastruktur berbasis proyek, investasi dan pemberdayaan industri yang manfaat jangka panjangnya dapat dinikmati oleh masyarakat. Jika dibandingkan dengan berhutang maka sukuk menjadi pilihan yang lebih baik karena adanya unsur kerjasama investasi, berbagi keuntungan dan resiko serta adanya proyek riil/asset (Musari, 2009).

Beberapa kajian terkait perkembangan dan peran Sukuk Negara telah banyak dilakukan, Husnul Khotimah (2017) menyatakan bahwa peran dan konstribusi sukuk negara untuk membiayai pembangunan semakin meningkat dan pemerintah mulai mengurangi penggunaan utang luar negeri mengingat dampakny ayang semakin memberatkan anggaran negara. Angrum, dkk (2017) menyatakan bahwa sukuk terus mengalami peningkatan sejak tahun 2013 sehingga memiliki peran yang signifikan dalam pengembangan infrastruktur di Indonesia. Pemerintah diharapkan mampu memberikan kemudahan investor dalam berinvestasi sukuk. Berdasarkan pemaparan di atas, tulisan ini bertujuan untuk mengidentifikasi lebih jauh tentang perkembangan sukuk negara serta bagaimana kontribusinya bagi pembangunan infrastruktur negara termasuk pada saat terjadi pendemi Covid-19.

\section{Metode}

Jenis penelitian ini adalah kualitatif dengan metode library research analisis deskriptif dengan mempelajari berbagai literatur dan tulisan, baik dari buku, artikel, internet, yang berhubungan dengan masalah yang diangkat. Data yang digunakan dalam penelitian ini adalah data sekunder dengan teknik analisis data yang digunakan adalah telaah berbagai litetur, fenomena dan kajian akademik lainnya.

\section{Hasil dan Pembahasan}

\subsection{Pengertian Sukuk}

Sejak abad pertengahan, umat Islam sudah menggunakan istilah sukuk/obligasi syariah dalam perdagangan internasional sehingga dalam sejarah Islam kata sukuk bukan merupakan hal yang baru. Pada masa itu, para saudagar menggunakan sukuk sebagai sertifikat yang menunjukkan kewajiban keuangan yang muncul karena adanya aktifitas perdagangan dan komersial lainnya (Ayub, 2005). Sukuk merupakan bentuk jamak dari kata sakk dalam Bahasa 
Arab yang artinya sertifikat atau bukti kepemilikan. Sakk menjadi akar kata "cheque" dalam bahasa latin yang saat ini telah biasa digunakan dalam berbagai transaksi keuangan (Adam, 2005).

Sukuk memiliki makna yang sama dengan obligasi syari'ah. Dalam fatwa DSN-MUI Nomor.32/DSN-MUI/IX/2002 tentang Obligasi Syari'ah, mendefiniskan “obligasi syari'ah adalah suatu surat berharga jangka panjang berdasarkan prinsip syariah yang dikeluarkan emiten kepada pemegang obligasi syariah yang mewajibkan emiten membayar pendapatan kepada pemegang obligasi syari'ah berupa bagi hasil/margin/fee serta membayar kembali dana obligasi saat jatuh tempo.

Pada tahun 2006, pasar modal Indonesia mulai menggunakan istilah sukuk seiring dengan dikeluarkannya Peraturan Bapepam-LK Nomor IX.A.13 tentang Penerbitan Efek Syari'ah. Dalam peraturan tersebut, definisi Sukuk adalah Efek syariah berupa sertifikat atau bukti kepemilikan yang bernilai sama dan mewakili bagian yang tidak tertentu (tidak terpisahkan atau tidak terbagi (syuyu'/undivide share) atas : 1) Kepemilikan asset berwujud tertentu; 2) Nilai manfaat dan jasa atas proyek tertentu atau aktivitas investasi tertentu; atau 3) kepemilikan atas asset proyek tertentu atau aktivitas investasi tertentu. Sedangkan menurut POJK No.18/POJK.04/2015 tentang Penerbitan dan Persyaratan Sukuk, yang dimaksud dengan sukuk adalah Efek syariah berupa sertifikat atau bukti kepemilikian bernilai sama dan mewakili bagian yang tidak terpisahkan atau tidak terpisahkan atau terbagi (syuyu'/undivided share) atas asset yang mendasarinya.

Sukuk dikeluarkan sebagai pengimbang dari aset yang terdapat dalam neraca keuangan pemerintah, pemangku kebijakan moneter, perusahaan, bank dan lembaga keuangan serta bentuk entitas lainya yang menghimpun dana masyarakat. Sukuk dapat dikeluarkan oleh institusi pemerintah, perusahaan swasta, lembaga keuaangan maupun otoritas moneter (Karomah, 2008).

Berdasarkan beberapa pengertian di atas, dapat dirumuskan bahwa sukuk adalah surat berharga atau bukti kepemilikan asset berwujud sebagai instrument investasi berdasarkan prinsip syariah yang dikeluarkan oleh pihak penerbit sukuk di mana pemegang sukuk berhak memperoleh imbalan berupa bagi hasil/margin/fee dan sukuk dapat diperdagangkan.

\subsection{Karakteristik Sukuk}

Sukuk memiliki perbedaan fundamental dengan obligasi konvensional antara lain konsep imbalan/bagi hasil, adanya transaksi pendukung (underkying transaction) berdasarkan prinsip syariah dan adanya underlying asset. Lebih jelasnya beberapa karaketeristik sukuk adalah (Otoritas Jasa Keuangan, 2020):

a. Merupakan bukti kepemilikan atas underlying asset.

b. Memerlukan underlying asset, yaitu asset yang dijadikan sebagai objek atau dasar transaksi dalam kaitannya dengan penerbitan sukuk

c. Return/pendapatan sukuk berdasarkan kepada imbalan/proposi bagi hasil/nisbah/margin sesuai akad yang digunakan dalam penerbitan.

d. Jenis industry emiten,pendapatan emiten penerbit sukuk, dan penggunaan dana harus sesuai dengan prinsip syariat dan terhindar dari hal-hal yang diharamkan

e. Mekanisme sukuk sejak awal penerbitan hingga masa akhir penerbitan diawasi oleh pihak wali amanat dan Dewan Pengawas Syariah (DPS). 
Tabel 2. Perbandingan Sukuk dengan Obligasi

\begin{tabular}{|c|c|c|}
\hline Deskripsi & Obligasi & Sukuk \\
\hline Prinsip Dasar & $\begin{array}{lrr}\text { Utang piutang } & \text { antara } \\
\text { penerbit } & \text { obligasi } & \text { dan } \\
\text { investor. } & \text { Obligasi murni } \\
\text { mewakili } & \text { utang } & \text { pada } \\
\text { penerbit } & & \end{array}$ & $\begin{array}{l}\text { Kepemilikan bersama atas } \\
\text { suatu asset/manfaat atas } \\
\text { asset/jasa/proyek/investasi } \\
\text { tertentu atau mewakili pihak } \\
\text { yang memiliki asset/manfaat } \\
\text { atas } \\
\text { asset/jasa/proyek/investasi }\end{array}$ \\
\hline Sifat Instrumen & Instrumen pengakuan & $\begin{array}{l}\text { Sertifikat } \\
\text { kepemilikan/Penyertaan atas } \\
\text { suatu aset }\end{array}$ \\
\hline Penerbit & Pemerintah. korporasi & Pemerintah, korporasi \\
\hline $\begin{array}{l}\text { Aktivitas } \\
\text { penerbit }\end{array}$ & $\begin{array}{l}\text { Tidak terbatas pada } \\
\text { aktivitas usaha yang tidak } \\
\text { bertentangan dengan } \\
\text { prinsip syariah }\end{array}$ & $\begin{array}{l}\text { Terbatas hanya pada } \\
\text { aktivitas usaha yang tidak } \\
\text { bertentangan dengan prinsip } \\
\text { syariah }\end{array}$ \\
\hline Pemakaian Dana & Bebas & Harus sesuai prinsip syariah \\
\hline Pendapatan & Bunga/kupon, capital gain & $\begin{array}{l}\text { Bagi hasil, nisbah, fee atau } \\
\text { margin }\end{array}$ \\
\hline Underlying asset & Tidak perlu & Perlu \\
\hline
\end{tabular}

Sumber: Website OJK (data diolah)

Underlying asset menjadi salah satu hal fundamental yang menjadi pembeda antara sukuk dengan obligasi karena tanpa adanya underlying asset, surat berharga yang diterbitkan akan mempunyia sifat sebagai instrument utang karena tidak terdapat transaksi yang mendasari penerbitan sukuk tersebut/underlying transaction (DPS-DPJPU, 2017). Dalam POJK Nomor. 18/POJK.04/2015 tentang Penerbitan dan Persyaratan Sukuk pasal 3 disebutkan bahwa asset yang menjadi dasar Sukuk terdiri atas :

a. Asset berwujud tertentu (a'yan amujudat);

b. Nilai manfaat atas asset berwujud (manaful a'yan) tertentu baik yang sudah ada maupun yang akan ada;

c. Jasa (al khadamat) yang sudah ada maupun yang akan ada;

d. Asset proyek tertentu (maujudat masyru' mu'ayyan); dan/atau

e. Kegiatan investasi yang telah ditentukan (nasyath ististmarin khashah).

\subsection{Sukuk di Indonesia}

Berdasarkan pihak penerbitnya, sukuk di Indonesia dibagi menjadi (Prasetyo, 2017) :

a. Sukuk korporasi, yaitu sukuk yang diterbitkan oleh perusahaan atau korporasi, baik swasta ataupun BUMN;

b. Sukuk Negara, yaitu sukuk yang diterbitkan oleh pemerintah Republik Indonesia dalam hal ini Kementerian Keuangan. Sukuk negara dikenal juga dengan nama Surat Berharga Syariah Negara (SBSN). 


\subsubsection{Sukuk Korporasi}

Penerbit sukuk korporasi pertama kali di Indonesia adalah PT.Indosat, Tbk pada tahun 2002 senilai RP. 175 M menggunakan akad mudaharah dengan pihak yang menjamin emisinya adalah PT.AAA Sekuritas. Beberapa tahun kemudian, muncul emiten-emiten lain yang menerbitkan sukuk mudharabah, diantaranya PT. Berlian Laju Tangker, Tbk, PT. Bank Bukopin, PT.Bank Muamalat, PT. Ciliandra Perkasa dan PT. Bank Syariah Mandiri (Prasetyo, 2017).

Pada periode awal, dasar hukum yang mendasari penerbitan sukuk hanya fatwa DSN-MUI Nomor 32/DSN-MUI/IX/2002 tentang Obligasi Syariah karena belum adanya dasar hukum lain yang mengatur tentang sukuk. Baru pada tahun 2006, keluarlah Peraturan Pemerintah yang membenahi regulasi sukuk, yaitu Peraturan IX.A.13 tentang Penerbitan Efek Syariah yang kemudian disempurnakan dengan adanya Peraturan Otoritas Jasa Keuangan (POJK) Nomor. 18/POJK.04/2015 tentang Penerbitan dan Persyaratan Sukuk. Akad yang banyak digunakan dalam sukuk korporasi adalah akad mudahrabah dan akad ijarah.

Struktur sukuk yang menggunakan akad mudaharabah : Pertama, Emiten menerbitkan sukuk dengan akad mudharabah; Kedua, Underlying assests sebagai dasar penerbitan sukuk diperoleh dari dana hasil penerbitan sukuk yang diinvestasikan pada aktivitas usaha atau proyek; Ketiga, Laba atau keuntungan diperoleh dari aktivitas usaha atau usaha sebagai underlying assets disalurkan kepada para investor sebagai imbal hasil/margin sesuai nisbah yang disepakati secara periodic; Keempat, Dana investasi akan dikembalikan emiten kepada investor pada saat jatuh tempo, sesuai dengan nilai sukuk ketika penerbitan. (OJK, 2020)

Adapun struktur sukuk yang menggunakan akad ijarah : Pertama, Emiten menerbitkan sukuk dengan akad ijarah; Kedua, Dengan penerbitan sukuk ijarah tersebut, manfaat obyek ijarah dialihkan emiten kepada investor yang akan diterima oleh wali amanat sebagai pihak yang mewakili investor; Ketiga, Wali amanat sebagai wakil investor memberikan kuasa (akad wakalah) kepada emiten untuk menyewakan objek ijarah tersebut kepada pihak ketiga. Dalam hal ini, emiten bertindak sebagai mu'jir (pemberi sewa) yang menyewakan oyek ijarah kepada pihak ketiga yang bertindak sebagai musta'jir (penyewa); Keempat, Atas akad tersebut, pihak ketiga melakukan pembayaran biaya sewa kepada emiten secara periodic dan pengembalian dana ketika jatuh tempo. Kelima, Emiten melanjutkan pembayaran dari pihak ketiga kepada investor secara periodik dalam bentuk cicilan ijarah sesuai waktu yang disepakati dan memberikan sisa fee jarrahh ketika sukuk jatuh tempo (OJK, 2020).

\subsubsection{Sukuk Negara (SBSN)}

Menurut Undang-Undang Republik Indonesia Nomor.19 Tahun 2008 tentang Surat Berharga Syari'ah Negara menyebutkan, bahwa Surat Berharga Syariah Negara selanjutnya disingkat SBSN, atau dapat disebut Sukuk Negara adalah surat berbarga negara yang diterbitkan berdasarkan prinsip syari'ah sebagai bukti atas bagian penyertaan terbadap asset SBSN, baik dalam mata uang rupiah maupun valuta asing. Dalam Fatwa DSN-MUI No.69/DSN-MUI/VI/2008, Surat Berbarga Syariah Negara diterbitkan berdasarkan prinsip syariah, sebagai bukti atas kepemilikan asset SBSN, baik dalam uang rupiah maupun valuta asing.

Sukuk Negara atau SBSN diterbitkan oleh pemerintah Republik Indonesia yang dilaksanakan oleh Kementerian Keuangan (Prasetyo, 2017). Tujuan penerbitan SBSN menurut Pasal 4 UU Nomor 19 Tahun 20018 yaitu, SBSN diterbitkan dengan tujuan untuk membiayai Anggaran Pendapatan dan Belanja Negara termasuk pembangunan proyek. APBN yang deficit 
menyebabkan pemerintah menerbitkan sukuk negara. Faktor lainnya adalah posisi Indonesia yang telah menjadi negara berpenghasilan menengah sehingga pinjaman luar negeri dengan persyaratan lunak tidak bisa lagi dijadikan sebagai sumber utama dalam membiayai APBN (Suminto, 2015).

Derivatif dari tujuan penerbitan SBSN menurut Direktorat Pembiayaan Syariah Kementerian Keuangan yaitu : 1) Memperluas basis sumber pembiayaan anggaran negara, 2) Mendorong pengembangan pasar keuangan syariah; 3) Menciptakan benchmark di pasar keuangan syariah; 4) diversifikasi basis investor; 5) Mengembangkan alternatif instrument investasi; 6) Mengoptimalkan pemanfaatan Barang Milik Negara (BMN) ; 7) Membiayai pembangunan proyek infrastruktur; dan 8) Memanfaatkan dana-dana masyarakat yang belum terjaring oleh system keuangan konvensional (DPS-DJPU, 2015).

Melalui penerbitan SBSN (sukuk negara) sejak tahun 2008, pemerintah berusaha untuk terus mendorong kemajuan keuangan syari'ah dan pembangunan negara. Sukuk Negara telah menjadi investasi keuangan syariah yang penting dan diminati disamping juga sebagai instrument pembiayaan APBN yang turut berkontribusi langsung dalam pembangunan di dalam negeri. Beberapa peran Sukuk Negara antara lain (DPS-DJPPR, 2017) :

a. Menyediakan alternatif sumber pembiayaan APBN

b. Menyediakan instrument investasi dan likuiditas berbasis syariah

c. Mengembangkan pasar keuangan syariah

d. Menyediakan benchmark bagi penerbitan sukuk korporasi

Struktur akad yang dikembankan dalam SBSN adalah ijarah sale and Lease back, SBSN ijarah Al Khadamat, SBSN ijarah asset to be leased dan SBSN wakalah. Terdapat tujuh instrument Sukuk Negara yang ditujukan untuk investor individu maupun investor institusi, baik di pasar domestic maupun pasar internasional, yaitu (Website DJPPR, 2020) :

a. Sukuk Ritel. Penjualan sukuk ritel dilakukan kepada investor individu melalui Agen Penjual dengan minimal pembelian 1 juta Rupiah, imbalan/kupon, bersifat fixed dengan pembayaran setiap bulan dan dapat diperjualbelikan;

b. Islamic Fixed Rate (IFR). Penjualan IFR dilakukan melalui lelang dan private palacement kepada investor institusi. Imbalan bersifat fixed yang dibayarkan setiap 6 bulan sekali dengan mata uang rupiah. Sama dengan sukuk ritel, IFR dapat diperjualbelikan di pasar sekunder;

c. Surat Perbendaharaan Negara Syariah (SPSN). Penjualan SPNS dilakukan kepada investor melalui lelang dan private placement, imbalan berupa diskonto dan periode SPNS maksimal satu tahun;

d. Sukuk Dana Haji Indonesia (SDHI). Penjualan SDHI dilakukan kepada investor institusi Lembaga pengelola dana haji melalui private placement dengan imbalan berupa kupon bersifat fixed yang dibayarkan setiap bulan (mata uang rupiah). SDHI tidak bisa diperjualbelikan;

e. Project Based Sukuk (PBS). Penjualan PBS dilakukan kepada investor institusi melalui lelang dan private placement dengan underlying berupa proyek maupun kegiatan APBN. Imbalan berupa kupon bersifat fixed yang dibayarkan setipa enam bulan. Sukuk ini dapat diperjualbelikan ;

f. Sukuk Valas. Penerbitan sukuk valas dilakukan di pasar internasional dengan mata uang USD dengan system penjualan Joint Lead Manager (JLM);

g. Sukuk Tabungan. Penjualan sukuk ini dilakukan kepada investor individu Warga Negara Indonesia (WNI). Imbalan berupa kupon yang sifatnya floating with foor (semula fixed) dan dibayarkan setiap bulan. Sukuk ini tidak dapat diperjualbelikan tetapi memiliki fasilitas early redemption. 


\subsection{Sukuk Negara (SBSN) dan Pembangunan Infrastruktur}

Pertumbuhan ekonomi suatu negara sangat dipengaruhi oleh pembangunan infrastruktur. Infrastruktur yang memadai akan mendukung berbagai aktivitas ekonomi yang pada gilirannya akan berdampak pada pertumbuhan ekonomi dan akan mempengaruhi tingkat kesejahteraan masyarakat. Pentingnya pertumbuhan ekonomi melalui pembangungan infrastruktur mendorong pemerintah untuk terus berupaya menyediakan ketersediaan dana yang dibutuhkan, antara lain dengan menerbitkan SBSN atau Sukuk Negara. Jika dibandingakan dengan sumber dana lain, maka skema pembiayaan SBSN memiliki beberapa keunggulan, yaitu adanya kemananan bagi seluruh pihak yang terlibat, sejak mulai perencanaan hingga pelaksanaannya dan kemudahan dalam prosedur pengusulannya. Keunggulan tersebut membuat minat Kementerian dan Lembaga Negara untuk memanfaatkan pembiayaan proyeknya menggunakan SBSN semakin meningkat (LPKSI, 2019).

Tabel 3. Tahap Pembiayaan Proyek Sukuk Negara (SBSN)

\begin{tabular}{|l|l|l|}
\hline No & \multicolumn{1}{|c|}{ Tahap Kegiatan } & \multicolumn{1}{|c|}{ Penanggung Jawab } \\
\hline 1. & Persiapan dan Pengusulan Proyek & Kementerian/Lembaga \\
\hline 2. & $\begin{array}{l}\text { Persetujuan atas kesiapan dan kelayakan } \\
\text { proyek }\end{array}$ & Bappenas \\
\hline 3. & Pengalokasian Anggaran & Kemenkeu \\
\hline 4. & $\begin{array}{l}\text { Pelaksanaan : } \\
- \text { Konstruksi atau pengadaan } \\
- \text { Penerbitan SBSN } \\
\text { - Pembayaran }\end{array}$ & $\begin{array}{l}\text { - Kementerian/Lembaga } \\
\text { - Kemenkeu } \\
\text { - Kemenkeu }\end{array}$ \\
\hline 5. & $\begin{array}{l}\text { Pemantauan dan Evaluasi : } \\
- \text { Progress Fisik }\end{array}$ & $\begin{array}{l}\text { - Kementerian/Lembaga } \\
\text { dan Bappneas }\end{array}$ \\
\hline 6. & Pengerapan Dana & $\begin{array}{l}\text { Kemenkeu } \\
\text { Kementerian/Lembaga } \\
\text { dan Kemenkeu }\end{array}$ \\
\hline
\end{tabular}

Sumber : DJPPR Kemenkeu, 2018.

Penerbitan SBSN (Sukuk negara) Indonesia yang pertama kali adalah Islamic Fixed Rate (IFR) pada tanggal 26 Agustus 2008 yang diresmikan langsung oleh Menteri Keuangan Republik Indonesia saat itu, Sri Mulyani Indrawati. Penjualan IFR dilakukan melalui lelang dan private placement kepada investor institusi menggunakan akad ijarah and sale leased back dengan jangka waktu lebih dari satu tahun (Prasetyo, 2017). Setelah penerbitan perdana IFR di mana investornya merupakan institusi, pada bulan Januari 2009 pemerintah menerbitkan kembali SBSN yaitu Sukuk Ritel seri SR-01 dengan target investor individu Warga Negara Indonesia (WNI). Sukuk Ritel ini bertujuan untuk mengoptimpalkan pasar dalam negeri dan memobilisasi dana masyarakat untuk membiayai APBN serta membiayai pembangunan proyek infrastruktur di Indonesia. Penjualan Sukuk ritel kepada investor dilakukan melalui Agen Penjual menggunakan akad ijarah sale and leased back. (Kemenkeu, 2019).

Sukuk negara telah memberi kontribusi dalam pembiayaan infrastruktur yang terus mengalami peningkatan. Setelah adanya Peraturan Pemerintah Nomor 56 tahun 2011 tentang Pembiayaan Proyek Melalui Penerbitan SBSN, pengembangan pembiayaan infrastruktur melalui SBSN diaplikasi dengan penerbitan Sukuk Negara berbasis pembiayaan proyek atau Project Based 
Sukuk (PBS) di tahun 2012. Lebih lengkapnya,landasan hukum yang mendasari penggunaan Sukuk Negara (SBSN) untuk proyek pembangunan infrastruktur adalah (Kemenkeu, 2018) :

1) UU N0.19 Tahun 2008 tentang Surat Berharga Syariah Negara, Pasal 4 menyatakan bahwa "SBSN diterbitkan untuk membiayai pembangunan proyek";

2) PP No.56 Tahun 2011 tentang Pembiayaan Proyek Melalui Penerbitan SBSN;

3) PMK No.220/PMK.08/2015 tentang Tata Cara Pembiayaan Proyek/Kegiatan Melalui Penerbitan SBSN;

4) PMK No.25/PMK.05/2016 tentang Tata Cara Pelaksanaan Kegiatan yang Dibiayai Melalui Penerbitan SBSN;

5) PMK No.120/PMK.08/2016 tentang Tata Cara Pemantauan, Evaluasi dan Pelaporan Pembiayaan Proyek/Kegiatan yang Dibiayai Melalui Penerbitan SBSN

Adapun cakupan proyek yang bisa dibiayai oleh SBSN berdasarkan PP No.56 Tahun 2011 adalah pembangunan infrastruktur, peningkatan pelayanan public, pemberdayaan industry dalam negeri dan program pemerintah lainnya yang bersifat strategis. Masih berdasarkan PP No.56 Tahun 2011, persyaratan proyek yang dapat dibiayai oleh SBSN adalah :

1) Merupakan proyek Pemerintah Pusat;

2) Sesuai prioritas RPJM;

3) Memenuhi kroteria kesiapan dan kelayakan untuk dilaksanakan dari Bappenas;

4) Memperoleh persetujuan DPR;

5) Mendapatkan alokasi dalam APBN;

6) Memenuhi kriteria dan tidak bertentangan dengan prinsip syariah;

7) Tidak akan dipindahtangankan/dihapuskan selama menjadi asset SBSN.

Sejalan dengan tujuan penerbitan sukuk negara untuk membiayai APBN termasuk pembangunan proyek infrastruktur maka pemerintah semakin gencar untuk mengembangkan instrument-instrumen SBSN. Pengembangan SBSN untuk pembiayaan proyek infrastruktur mulai dilakukan pada tahun 2013 secara earmarked, yaitu Project Financing Sukuk dengan total nilai sepanjang tahun 2013-2018 mencapai Rp. 62,4 Trilun (DJPPR, 2019).

Pada tahun 2016, pemerintah kembali menerbitkan SBSN dengan target investor individu Warga Negara Indonesia, yaitu Sukuk Tabungan dengan seri ST-001. Sukuk Tabungan ini merupakan bukti kesungguhan pemerintah dalam mengembangkan pembiayaan APBN serta mendukung pengembangan pasar keuangan syariah di Indonesia. Imbal hasil yang ditawarkan pada seri pertama adalah fixed, baru kemudian di penerbitan kedua imbal hasil menjadi floating with floor (Kemenkeu, 2019).

Selama kurun waktu 11 tahun (2008- 2019) sejak penerbitan Undang-Undang tentang SBSN, sukuk negara telah mengalami perkembangan yang cukup signfikan, di antaranya jumlah penerbitan sukuk yang semakin meningkat serta jenis instrumennya yang semakin bervasiasi. Sampai tanggal 31 Desember 2019, jumlah penerbitan SBSN mencapai Rp. 1230,44 Triliun dengan total outstanding SBSN mencapai RP. 740,62 triliun atau sekitar 18\% dari total outstanding Surat Berharga Negara dengan Project Based Sukuk (PBS) sebagai instrument SBSN dengan prosi paling besar. Total penerbitan SBSN setiap tahun terus mengalami peningkatam. Sepanjang tahun 2018, penerbitan SBSN mencapai Rp. 213,89 dan pada 2019 meningkat sebesar 17,20\% yaitu mencapai Rp. 258,31 Triliun. Meningkatnya jumlah penerbitan ini disebabkan karena adanya keperluan pembiayaan yang meningkat sejalan dengan meluasnya deficit APBN (LPKSI, 2019). 
Tabel 3. Outstanding Sukuk Negara Tahun 2019

\begin{tabular}{|ll|l|l|}
\hline Sukuk Negara Tahun 2019 & $\begin{array}{l}\text { Outstanding } \\
\text { (Rp Triliun) }\end{array}$ & $\begin{array}{l}\text { Porsi } \\
\mathbf{( \% )}\end{array}$ \\
\hline PBS & Project Based Sukuk & 421,30 & 55,67 \\
\hline SNI & Sukuk Negara Indonesia & 208,52 & 28,15 \\
\hline SR & Sukuk Ritel & 43,59 & 5,89 \\
\hline SDHI & Sukuk Dana Haji Indonesia & 28,20 & 3,81 \\
\hline SPNS & $\begin{array}{l}\text { Surat Perbendaharaan Negara } \\
\text { Syariah }\end{array}$ & 21,56 & 2,91 \\
\hline ST & Sukuk Tabungan & 14,09 & 1,90 \\
\hline IFR & Islamic Fixed Rate & 8,08 & 1,09 \\
\hline $\begin{array}{l}\text { PBS- } \\
\text { USD }\end{array}$ & PBS dalam mata uang USD & 2,78 & 0,38 \\
\hline PBS-NT & PBS Non-Tradable & 1,50 & 0,20 \\
\hline Total & & $\mathbf{7 4 0 , 6 2}$ & $\mathbf{1 0 0 , 0 0}$ \\
\hline
\end{tabular}

Sumber : LPKSI Kemenkeu, 2019.

Gambar 1. Perkembangan Penerbitan Sukuk Negara

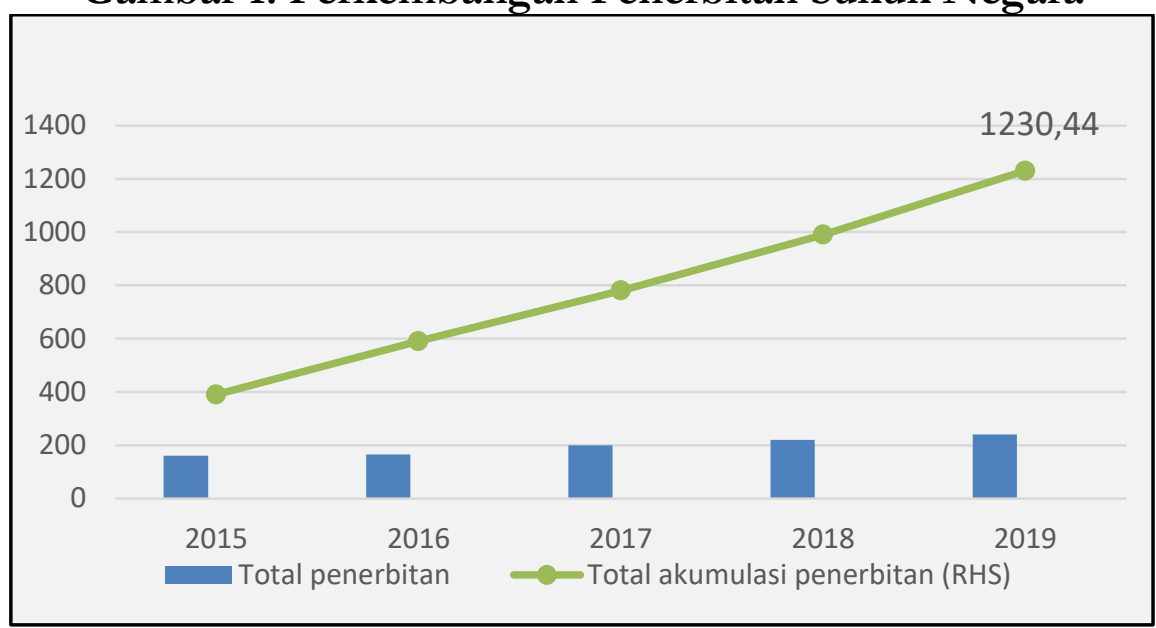

Sumber : LPKSI Kemenkeu, 2019 (data diolah)

Gambar 2. Perkembangan Nilai Outstanding Sukuk Negara

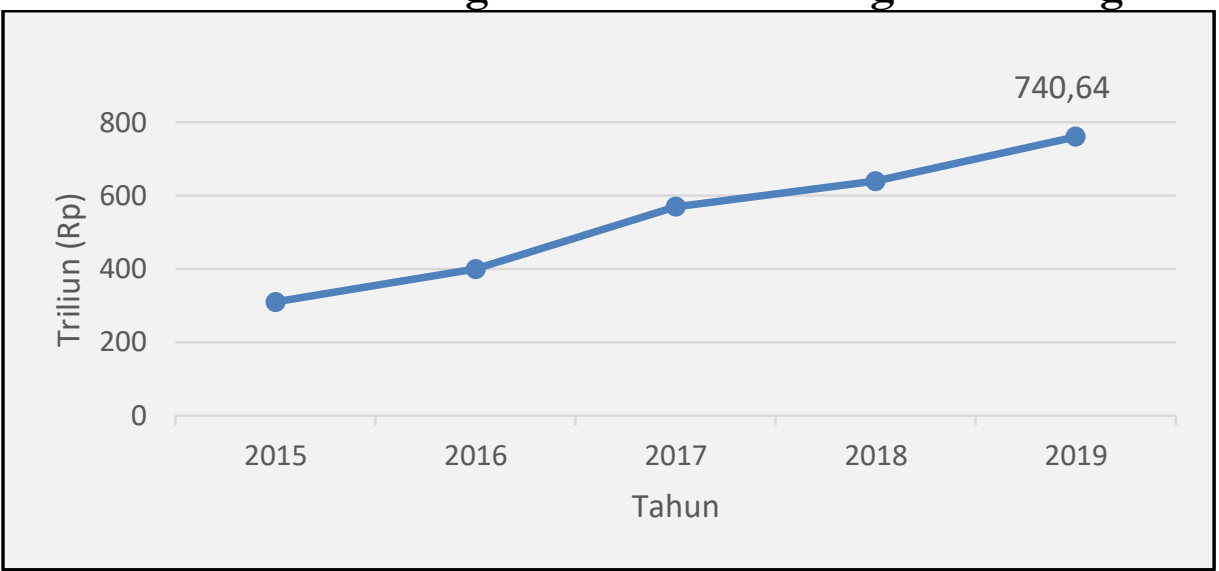

Sumber : LPKSI Kemenkeu, 2019 (data diolah) 
Untuk SBSN ritel (Sukuk Ritel dan Sukuk Tabungan) sepanjang tahun 2019, dilakukan penerbitan dengan frekuensi 5 kali dalam satu tahun. Hal ini merupakan upaya mengoptimalkan peran serta masyarakat dalam pembiayaan APBN. Pada tahun 2019, pemerintah menerbitkan green retail sukuk pertama, yaitu Sukuk Tabungan seri ST006 yang menunjukkan komitmen pemerintah dalam upaya mengembangkan keuangan syariah sekaligus berkontribusi dalam mengatasi berbagai isu iklim dan lingkungan (LPKSI, 2019)

Di tengah pendemi Covid 19 tahun 2020, pemerintah kembali menerbitkan Sukuk Ritel Negara seri SR013. Walaupun dalam kondisi pasar keuangan Indonesia yang tidak pasti akibat Covid 19 namun antusiasme masyarakat untuk berinvestasi masih tinggi. Hal tersebut berdasarkan nilai total penjualan SR013 yang mencapai Rp. 25,665 Triliun dengan total investor sebanyak 44.803. Penjualan ini merupakan pencapaian terbesar sepanjang penerbitan SBN Ritel online sejak tahun 2018. Hal yang cukup menarik dalam penjualan SR013 ini adalah dominasi investor generasi milenial (usia 19-39 tahun) sebanyak 36,59\%. Hasil penjualan SR)13 ini selain akan digunakan untuk membiayai proyek infrastruktur juga ditujukan untuk pemulihan ekonomi akibat pendemi Covid-19 (DJPPR, 2020).

Dalam kurun tahun 2013 - 2020, SBSN telah membiayai 2937 proyek dengan nilai total pembiayaan Rp. 118,3 Triliun, Adapun sebaran alokasi pembiayaan proyek yang dibiayai oleh SBSN dari tahun 2013-2020 antara lain (DJPPR, 2020) :

a. Proyek jalan dan jembatan, sebanyak 592 proyek, dengan nilai Rp. 41,4 Triliun;

b. Proyek Sumber Daya Air, sebanyak 576 proyek dengan nilai Rp. 21,5 Triliun;

c. Proyek transportasi, sebanyak 89 proyek dengan nilai Rp. 39,5 Triliun;

d. Proyek pendidikan, sebanyak 474 proyek dengan nilai Rp. 10,2 Triliun;

e. Proyek keagamaan, sebanyak 1176 proyek, dengan nilai RP. 4,1 Triliun;

f. Proyek taman nasional, sebanyak 15 proyek dengan nilai Rp. 0,3 Triliun;

g. Proyek Laboratorium, sebanyak 15 Proyek senilai Rp. 1,3 Triliun.

Penerbitan Sukuk Negara dengan bermacam seri yang menggunakan underlying asset berupa proyek infrastruktur, menyebabkan semakin meluasnya ruang fiscal APBN. Pendanaan pembangunan infrastruktur yang seharusnya berada pada sisi Belanja Negara, dipindahkan sebagian ke sisi Pembiayaan sehingga ruang di sisi Belanja Negara dapat ditambah untuk dapat dimanfaarkan dalam pembiayaan infrastruktur lainnya. Dengan demikian, akan semakin banyak proyek pemerintah yang bisa dibiayai baik dari sisi Belanja maupun Pembiayaan Sukuk Negara. Di sisi lain, Sukuk Negara mendorong pengelolaan proyek infrastruktur menjadi lebih tertib baik dalam perencanaan, pelaksanaan maupun penarikan dana sesuai dengan yang direncanakan. Dalam akad yang disepakati, salah satu persyaratannya adalah proyek diselesaikan sesuai dengan waktu yang ditentukan. Proyek yang tidak diselesaikan tepat waktu menyebabkan ketidaksesuian realisasi dengan akad dapat menimbulkan akibat hukum yang lebih kompleks (Hariyanto).

\section{Kesimpulan}

Permasalahan utang luar negeri dan infrastruktur di Indonesia merupakan dua hal yang berkaitan. Berbagai upaya telah dilakukan pemerintah agar infrastruktur terus berkembang tanpa menambah beban utang luar negeri bagi negara. Salah satu upaya yang dilakukan pemerintah adalah menerbitkan Surat Berharga Syariah Negara atau SBSN. 
Sukuk Negara merupakan salah satu instrument keuangan syariah yang muncul seiring dengan perkembangan industry keuangan syariah yang berjalan sangat dinamis saat ini. Tidak hanya sebagai instrument investasi syariah, Sukuk Negara juga memiliki peran sebagai sumber permbiayaan APBN pengganti utang luar negeri, yang digunakan untuk pembangunan infrastruktur di Indonesia. Penerbitan SBSN juga menambah alternatif pilihan investasi syariah yang sangat menarik karena aman, mudah, memiliki kepastian pembayaran imbalan dan pengembalian pokok karena dijamin oleh pemerintah. Keunggulan lain dari Sukuk Negara ini adalah tersedianya instrument sukuk yang dikhususkan untuk setiap individu WNI melalui seri Sukuk Negara Ritel dan Sukuk Negara Tabungan sehingga selain dapat mengembangkan asset pribadi, masyarakat juga dapat berperan serta dalam pembangunan negara.

Pada prinsipnya terdapat beberapa hal yang membedakan antara Sukuk Negara dengan obligasi, di antaranya perlunya Underlying asset sebagai dasar penerbitan Sukuk Negara. Undang-Undang No.19 Tahun 2008, menjadi dasar hukum utama pemerintah dalam mengimplemantasikan berbagai kebijakan terkait SBSN atau Sukuk Negara. Beragamnya seri Sukuk Negara yang diterbitkan pemerintah menunjukkan keseriusan pemerintah dalam mendukung perkembangan industry keuangan syariah di Indonesia sekaligus sebagai solusi terhadap masalah deficit yang terdapat dalam anggaran belanja negara, terutama anggaran infrastruktur. Dengan adanya Sukuk Negara, ruang fiscal anggaran negara menjadi lebih luas sehingga pemerintah dapat mengalokasikan sumber-sumber pendapatan negara lainnya untuk pembiayaan infrastruktur.

Sejak awal penerbitannya pada tahun 2008, Sukuk Negara terus bergerak positif, baik dari nilai total penerbitan dan outstanding maupun dari jumlah investor yang semakin meningkat, termasuk saat pendemi Covid-19 yang tidak mengurangi antusiasme investor untuk tetap berinvestasi pada Sukuk Negara (Ritel). Peningkatan tersebut berpengaruh terhadap jumlah pembiayaan yang semakin meningkat serta jumlah proyek infrastruktur yang semakin besar dan merata. Pada tahun 2019, Sukuk Negara telah membiayai 619 proyek pada 14 sektor yang tersebesar di 34 propinsi. Hal tersebut mengindikasikan bahwa potensi dan kinerja sukuk semakin baik dalam berkontribusi terhadap pembangunan negara.

\section{Referensi}

Abdul, Dede.(2011). Perkembangan Obligasi Syariah (Sukuk) di Indonesia : Analisis Peluang dan Tantangan. Jurnal Al-'Adalah Vol.X No.1 Januari 2011.

Adam, N.J.,(2005). Sukuk : A Panaceafor Converegence and Capital Market Developmnet in the OIC Cointries. Paper presented at $6^{\text {th }}$ International Conference on Islamic Economics and Finance. Jakarta, November 21-24.

Amaliah, Ima \& Tasya Aspiranti. (2017). State Sukuk Potential in Reducing Indonesia Budget Deficit 2009 - 2015. Journal of Economics, Business and Accountancy Venture Vol.20, No.1, April-July 2017, pages 21-30. DOI: 10.144/jebav.v20il

Ayub, N. (2005). Securitization, Sukuk, Fund Management Potential to be Realized by Islamic Financial Institutions. Paper presented at $6^{\text {th }}$ international Conference on Islamic Economics and Finance, Jakarta, Indonesia, November 21-24.

Huda, Nurul \& Mustafa Edwin.(2007). Investasi pada Pasar Modal Syariah. Jakarta : Kencana Prenada Media Group.

Karomah, Umi Yaumidin.(2008). Investasi Syariah Implementasi Konsep pada Kenyataan Empirik. (Sukuk : Sebuah Alteratif Instrumen Investasi). Yogyakarta : Kreasi Wacana. 
Khotimah, Husnul (2017). Sukuk dan Kontribusinya dalam Pembiayaan Pembangunan. Optimal : Jurnal Ekonomi dan Kewirausahaan. Vol 11 no.1 2017 hal 83-103.

Prasetyo, Yoyok. (2017). Hukum Investasi dan Pasar Modal Syariah. Bandung : CV Mitra Syariah (Mina).

Pratiwi, Angrum dkk, (2017). Peran Sukuk Negara dalam Pembiayaan Infrastruktur. Al-Tijary Jurnal Ekonomi dan Bisnis Islam Vol 2. No.2 Hal 155-176. P-ISSN : 240-9404; E-ISSN : 2460-9412.

Direktorat Pembiayaan Syariah (DPS) \& Direktorat Jenderal Pengelolaan Utang (DJPU) Kementerian Keuangan. Mengenal Sukuk: Instrumen Investasi Berbasis Syariah.

Direktorat Pembiayaan Syariah (DPS) \& Direktorat Jenderal Pengelolaan Pembiayaan dan Resiko (DJPPR) Kementerian Keuangan (2017). Investasi Syariab Melalui Surat Berbarga Syariah Negara (Sukuk Negara). Jakarta.

Direktorat Jenderal Pengelolaan Pembiayaan dan Resiko (DJPPR) Kementerian Keuangan. (2018). Pembiayaan Proyek Infrastruktur Melalui Penerbitan SBSN/Sukuk Negara. Bali.

Musari K \& Ismail. (2019). Menggagas Sukuk Sebagai Instrumen Fiskal dan Moneter. Bisnis Indonesia Daily Newspaper.

Suminto, (2015). Sukuk Negara. Jakarta : Direktorat Jenderal Pengelolaan Risiko.

Tim Otoritas Jasa Keuangan dan Pasar Modal Syariah. Mengenal Pasar Modal Syariah.

\section{Website}

Direktorat Jenderal Pengelolaan Pembiayaan dan Resiko (DJPPR) Kementerian Keuangan, https:/ / www.djppr.kemenkeu.go.id/

Hariyanto, Eri. Peran Strategdis Sukuk Negara Ditjen Pengelolan Pembiayaan dan Resiko, Kementerian Keuangan. bttps:/ / www.djppr.kemenkeu.go.id

Eri. Peluang Pembiayaan Infrastruktur Melalui Sukuk Negara. Ditjen Pengelolan Pembiayaan dan Resiko, Kementerian Keuangan. https://www.djppr.kemenkeu.go.id

Kementerian Keuangan. RAPBN 2019.https:// wmw.kemenkeu.go.id/ rapbn2019

, Alokasi Pembiayaan Proyek SBSN tahun 2019 meningkat Menjadi Rp. 28,43 Triliun.

https://www.kemenkeu.go.id/publikasi/siaran-pers/keterangan-pers-alokasi-pembiayaanproyek-sbsn-tahun-2019-meningkat-menjadi-rp28-43-triliun/

Otoritas Jasa Keuangan (OJK). https://www.ojk.go.id/id/kanal/syariah/

Otoritas Jasa Keuangan (OJK). Laporan Perkembangan Keuangan Syariah (LPKSI) 2019.

https:/ / wmm.ojk.go.id/id/ kanal/syariah/data-dan-statistik/laporan-perkembangan-keuangan-syariahindonesia/ default.aspx

Undang-Undang No.19 Tahun 2018 tentang Surat Berharga Syariah Negara

Peraturan Otoritas Jasa Keuangan (POJK) Nomor 18/POJK.04/2015 tentang Penerbitan dan Persyaratan Sukuk 